\title{
Renal cell carcinoma metastases to the maxillary sinus
}

\author{
Eugene Hung Chih Wong, ${ }^{1}$ Nora Tetter, ${ }^{1}$ Katharina Glatz, ${ }_{1}^{2}$ Yves Brand ${ }^{1}$
}

${ }^{1}$ Department of

Otorhinolaryngology, Head and Neck Surgery, University Hospital Basel, Basel,

Switzerland

${ }^{2}$ Institute of Pathology, Universitatsspital Basel, Basel, Switzerland

\section{Correspondence to}

Dr Yves Brand,

yves.brand@unibas.ch

Accepted 9 October 2017

\section{SUMMARY}

Metastasis of renal cell carcinoma (RCC) to the head and neck region is rare. We report the case of a 65 -yearold man with history of RCC, presented 7 years after nephrectomy, adrenalectomy and lung metastasectomy for his primary tumour, with symptoms of nasal obstruction, postnasal drip, productive cough and pressure sensation in the left maxillary sinus. CT revealed a unilateral, irregular opacification in the left maxillary sinus with bony erosion of the infraorbital canal wall. A yellow cystic lesion was completely removed from the maxillary sinus during functional endoscopic sinus surgery and histopathological analysis confirmed the diagnosis of a metastatic RCC. Patient continued to be managed with his pre-existing treatment for advanced RCC.

\section{BACKGROUND}

Renal cell carcinoma (RCC) accounts for about $85 \%$ of primary renal tumours ${ }^{1}$ and usually affects men aged between 30 and 60 years. ${ }^{2}$ Clear cell renal cancer is the most common histological subtype of RCC and accounts for $70 \%-80 \%$ of all RCCs. ${ }^{3}$ RCC usually metastasises to regional lymph nodes, lungs, bones and liver, ${ }^{1}$ but rarely to the head and neck region. ${ }^{4}$ We report a rare case of a male patient, with metastases of RCC to the maxillary sinus, 7 years after nephrectomy for primary RCC.

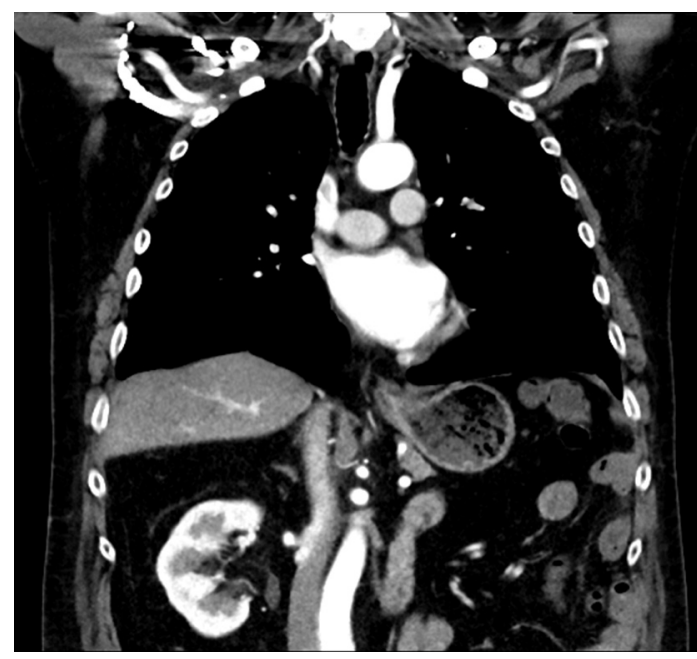

Figure 1 Coronal CT scan of patient's thorax and abdomen showing evidence of previous left nephrectomy and adrenalectomy.

\section{CASE PRESENTATION}

A 65 -year-old man presented with few years history of nasal obstruction and new onset of postnasal drip and intermittent productive cough following a recent cold. He also described pressure sensation in the left maxillary sinus but no smell disturbances. These symptoms persisted despite being treated with 6 weeks of maximum medical therapy for rhinosinusitis. He was diagnosed with RCC with hepatic and pulmonary metastasis (pT3a, cN2 and pM1) 7years prior to this where he underwent chemotherapy, tumour nephrectomy and adrenalectomy (figure 1) as well as open metastasectomy of both lungs. He has been managed with targeted therapies (lenvima and everolimus) since then with partial remission. Ear, nose and throat examination showed a septal deviation to the right side and prominent middle turbinates. There were no intranasal signs of infection or nasal polyps.

\section{INVESTIGATIONS}

CT revealed a unilateral, irregular opacification in the left maxillary sinus (figure 2 ) with bony erosion of the infraorbital canal wall.

\section{TREATMENT}

He underwent functional endoscopic sinus surgery under general anaesthesia where endoscopic septoplasty and reduction of middle turbinate were first performed to optimise surgical access. Uncinectomy was then performed to allow opening and access to the left maxillary sinus. Macroscopically, a yellow cystic lesion was observed in the left maxillary sinus, which was completely removed. The operation was uneventful with no major bleeding and patient made good recovery without any significant postoperative complications.

\section{OUTCOME AND FOLLOW-UP}

Histological examination revealed fragments of a necrotic tumour compatible with clear cell RCC (figure 3). The epithelial nature of the necrotic cells could be confirmed by focally retained immunohistochemical staining of the necrotic cells with a pan-cytokeratin antibody. Due to patient's advanced disease stage, no additional treatment was added to his pre-existing management of metastatic RCC. Patient had a CT scan 3 months postoperatively, which showed no tumour recurrence. Clinical examination at his last follow-up (7 months after the surgery) did not show any signs of locoregional recurrence either. 

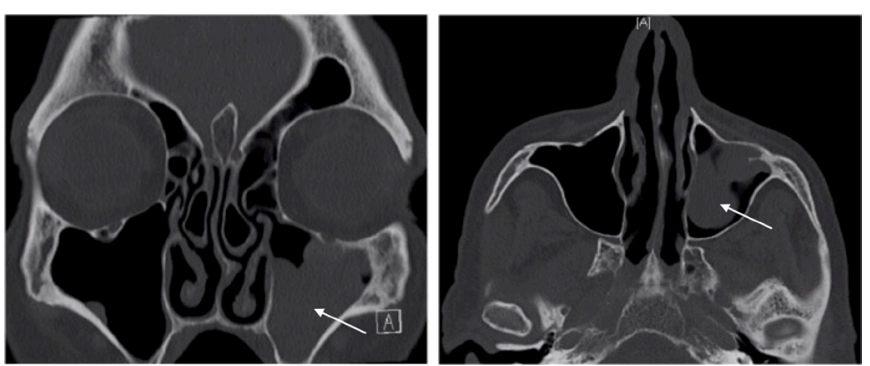

Figure 2 Coronal and axial CT scan of the patient showing a unilateral, irregular opacification in the left maxillary sinus (arrow) with bony erosion of the infraorbital canal wall.

\section{DISCUSSION}

The clinical course of primary RCC is often unpredictable ${ }^{5}$ where some patients had spontaneous regression ${ }^{6}$ while others presenting with metastases few years after resection of primary tumour. ${ }^{6}$ The rate of solitary late recurrences (more than 10 years) of RCC ranges from $4.7 \%$ to $11 \%$. $^{7}$ Alternatively, symptoms of tumour metastasis also can be the presenting sign which leads to the diagnosis of renal malignancy. ${ }^{8-13}$ In $7.5 \%$ of patients with RCC, head and neck metastases were the presenting complaint. ${ }^{8}$

Metastases of RCC to the head and neck region only account for about $15 \%-30 \%$ of all cases ${ }^{45}$ and the common sites involved in this region include the parotid glands, larynx, thyroid, mandible and paranasal sinuses. ${ }^{14}$ Metastases from RCC to the nose and paransal sinuses are rare, with less than 100 cases being reported in the literature. ${ }^{8} \mathrm{~A}$ review of 98 paranasal metastases revealed that $54 \%$ of the cases originated from RCC with a predilection for the maxillary antrum (36\%), ethmoid sinus (25\%), frontal sinus (17\%) and nasal cavity (11\%). ${ }^{15}$ Sinonasal metastases are usually associated with metastasis to other organs while single site metastasis in the head and neck region from RCC is a rare occurrence. ${ }^{16}$

The metastatic deposits from RCC are normally vascular in nature and patients often present with epistaxis in $70 \%$ of cases. ${ }^{117}$ Other symptoms of RCC in paranasal sinus that has been described include nasal obstruction and facial pain. ${ }^{18}$

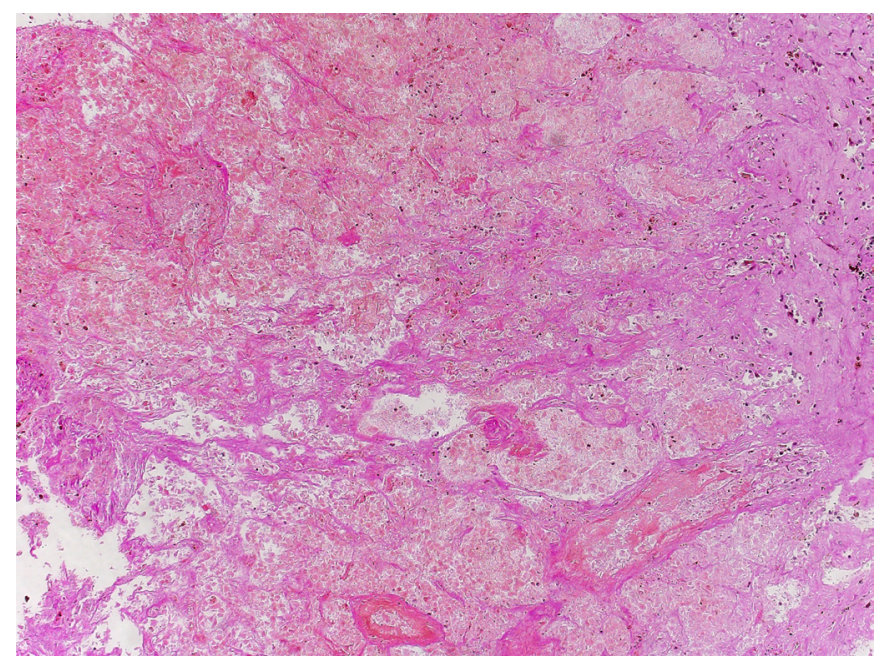

Figure 3 Biopsy from the sinonasal mucosa with completely necrotic metastasis of a clear cell renal cell carcinoma. In this Elastica van Gieson (EvG) staining for connective tissue, the characteristic nested growth pattern of clear cell renal cell carcinomas is clearly discernible. EvG, 100x.

\section{Learning points}

- Renal cell metastasis to the paranasal sinuses is possible even after many years following nephrectomy of the primary tumour.

- When evaluating patients with unilateral sinonasal symptoms without signs of infections, it is crucial to obtain a good medical and surgical history as patients' renal cell carcinoma (RCC) treatment may have occurred very long time ago.

- Clinicians should have high index of suspicion for RCC metastasis as a differential diagnosis in patients with history of RCC and presenting with epistaxis, nasal obstruction or facial pain.

- Clinicians should be careful with taking biopsies of such metastases, as they are normally very vascular.

- Surgical resection is the treatment of choice for this disease.

Clinical suspicion should be raised in patients with unilateral sinonasal lesion, unresponsive to medical management or with associated cranial neuropathies, ${ }^{19}$ and patients with such clinical presentations, combined with histories of RCC, should alert clinicians of the differential diagnosis of RCC metastasis.

It is advisable to do a contrast CT scan of the paranasal sinuses to evaluate the vascularity of the lesion before planning for biopsy to avoid uncontrolled haemorrhage ${ }^{20}$ as well as to determine the extent of the mass and delineate any bony breakdown. ${ }^{19}$

The role of surgery is to achieve adequate local resection, which allows for histopathological confirmation of diagnosis 58 and appropriate short-term palliation of symptoms. ${ }^{4}$ Small localised disease in the paranasal region can be resected endoscopically to decrease postoperative morbidity, although in patients with more extensive diseases with intracranial or intraorbital extension, endoscopic-assisted craniofacial debulking or open approach may be required for adequate resection. ${ }^{20}$

The 5-year survival of patients with systemic metastatic RCC was only $8 \% .^{21}$ On the other hand, the 5 -year survival of patients after excision of solitary metastatic RCC lesions following nephrectomy was found to be $13 \%-35 \%,{ }^{42}$ regardless of the time interval between nephrectomy and diagnosis of metastatic lesion. ${ }^{4}$ Despite the low survival rate, radical excision still provide the best hope for long-term survival in such patients. ${ }^{5}$

For patients unsuitable for surgery, other forms of treatment has been advocated, for example, chemotherapy and radiotherapy, although metastatic RCCs have relatively poor response to these agents. ${ }^{72}$ Other alternatives include immunotherapy (eg, interferon- $\alpha$ and interleukin-2) and targeted therapies. ${ }^{3}$

Contributors All authors contributed to this case report. The conception for this work was by YB. YB and NT treated the patient during this hospitalisation in the ENT department. KG performed the histological examination. NT collected the data and EHCW wrote the manuscript. All the coauthors revised the draft critically and approved it for publication.

Competing interests None declared.

Patient consent Obtained.

Provenance and peer review Not commissioned; externally peer reviewed.

(c) BMJ Publishing Group Ltd (unless otherwise stated in the text of the article) 2017. All rights reserved. No commercial use is permitted unless otherwise expressly granted.

\section{REFERENCES}

1 Vreugde S, Duttmann R, Halama A, et al. Metastasis of a renal cell carcinoma to the nose and paranasal sinuses. Acta Otorhinolaryngol Belg 1999;53:129-31. 
2 Simo R, Sykes AJ, Hargreaves SP, et al. Metastatic renal cell carcinoma to the nose and paranasal sinuses. Head Neck 2000;22:722-7.

3 Sountoulides P, Metaxa L, Cindolo L. Atypical presentations and rare metastatic sites of renal cell carcinoma: a review of case reports. J Med Case Rep 2011:5:429.

4 Som PM, Norton KI, Shugar JM, et al. Metastatic hypernephroma to the head and neck. AJNR Am J Neuroradiol 1987:8:1103-6.

5 Jung JW, Yoon SC, Han DH, et al. Metastatic renal cell carcinoma to the orbit and the ethmoid sinus. J Craniofac Surg 2012;23:e136-e138.

6 Pantuck AJ, Zisman A, Belldegrun A. Gene and immune therapy for renal cell carcinoma. Int J Urol 2001;8:S1-S4.

7 Prescher A, Brors D. [Metastases to the paranasal sinuses: case report and review of the literature]. Laryngorhinootologie 2001;80:583-94.

8 Alvarez-Múgica M, Bulnes Vázquez V, Jalón Monzón A, et al. Late recurrence from a renal cell carcinoma: solitary right maxilar mass 17 years after surgery. Arch Esp Urol 2010;63:147-50

9 Lee HM, Kang HJ, Lee SH. Metastatic renal cell carcinoma presenting as epistaxis. Eur Arch Otorhinolaryngol 2005;262:69-71.

10 Azarpira N, Ashraf MJ, Khademi B, et al. Distant metastases to nasal cavities and paranasal sinuses case series. Indian J Otolaryngol Head Neck Surg 2011;63:349-52.

11 Matsumoto Y, Yanagihara N. Renal clear cell carcinoma metastatic to the nose and paranasal sinuses. Laryngoscope 1982;92:1190-3.
12 Ikeuchi T, Asai N, Hori T, et al. [Renal cell carcinoma detected by metastasis to the frontal sinus: a case report]. Hinyokika Kiyo 1998;44:89-92.

13 Parida PK. Renal cell carcinoma metastatic to the sinonasal region: three case reports with a review of the literature. Ear Nose Throat J 2012;91:E11-16.

14 Gottlieb MD, Roland JT. Paradoxical spread of renal cell carcinoma to the head and neck. Laryngoscope 1998;108:1301-5.

15. Bernstein JM, Montgomery WW, Balogh K. Metastatic tumors to the maxilla, nose, and paranasal sinuses. Laryngoscope 1966;76:621???650-50.

16 Choong CV, Tang T, Chay WY, et al. Nasal metastases from renal cell carcinoma are associated with Memorial Sloan-Kettering Cancer Center poor-prognosis classification. Chin J Cancer 2011;30:144-8.

17 Stodulski D, Stankiewicz C, Skorek A. [Renal cell carcinoma metastases to the head and neck]. Otolaryngol Pol 2006;60:893-9.

18 Godley PA, Stinchcombe TE. Renal cell carcinoma. Curr Opin Oncol 1999;11:213-7.

19 London NR, Reh DD. Differential diagnosis of chronic rhinosinusitis with nasal polyps. Adv Otorhinolaryngol 2016;79:1-12.

20 Ishak Al, Md Pauzi SH, Masir N, et al. Multiple metastatic deposits in the head and neck region from a renal cell carcinoma. Malays J Med Sci 2010;17:71-4.

21 Choueiri TK, Motzer RJ. Systemic therapy for metastatic renal-cell carcinoma. N Engl J Med 2017;376:354-66.

22 Sgouras ND, Gamatsi IE, Porfyris EA, et al. An unusual presentation of a metastatic hypernephroma to the frontonasal region. Ann Plast Surg 1995;34:653-6.

Copyright 2017 BMJ Publishing Group. All rights reserved. For permission to reuse any of this content visit

http://group.bmj.com/group/rights-licensing/permissions.

BMJ Case Report Fellows may re-use this article for personal use and teaching without any further permission.

Become a Fellow of BMJ Case Reports today and you can:

- Submit as many cases as you like

- Enjoy fast sympathetic peer review and rapid publication of accepted articles

- Access all the published articles

Re-use any of the published material for personal use and teaching without further permission

For information on Institutional Fellowships contact consortiasales@bmjgroup.com

Visit casereports.bmj.com for more articles like this and to become a Fellow 